Robert Kantor, Struktura sądów Kościoła rzymskokatolickiego według Kodeksu prawa kanonicznego z 1917 roku, [w:] Struktura i działalność Sądu Diecezjalnego w Tarnowie w latach 1945-1983, red. Robert Kantor, Kraków 2019, s. 9-20.

DOI: http://dx.doi.org/10.15633/9788374385299.02

KS. ROBERT KANTOR

Uniwersytet Papieski Jana Pawła II w Krakowie

\title{
Struktura sądów Kościoła rzymskokatolickiego według Kodeksu prawa kanonicznego z 1917 roku
}

W Kościele, w którym wszyscy powołani są do świętości, należy szczególnie troszczyć się o sprawiedliwość. Polega ona nie tylko na przestrzeganiu prawa moralnego, ale także na respektowaniu prawa Bożego oraz prawa ludzkiego. Troska o przestrzeganie prawa moralnego leży w kompetencji władzy duchowej. Ochrona przestrzegania prawa w sensie ścisłym jest szczególnym obowiązkiem władzy sądowniczej. Winna ona zawsze mieć świadomość, że jest ludzką realizacją idei Bożej sprawiedliwości. Dążenie do sprawiedliwości, jej ochrona i przywracanie wynikają nie tylko z przepisów prawa kanonicznego, ale także z podstawowego posłannictwa Kościoła, którego podstawowym zadaniem jest budowanie sprawiedliwości ${ }^{1}$.

Trybunał to miejsce wyniosłe, $\mathrm{z}$ którego w państwie rzymskim najwyższy urzędnik sądził sprawy obywateli lub cudzoziemców, stąd - to miejsce wydawania wyroków. Wśród wielu kryteriów podziału sądów (trybunałów) jest to ze względu na instancję. Według niego sądy dzielimy na pierwszej, drugiej i dalszej instancji ${ }^{2}$.

1 Por. R. Sztychmiler, Sądownictwo kościelne w służbie praw człowieka, Olsztyn 200o, S. 22.

2 Por. F. Bączkowicz, Prawo kanoniczne. Podręcznik dla duchowieństwa, t. 3, wyd. 3, Opole 1958, s. 19-20. 
Niniejsze opracowanie zmierza do ukazania struktury sądów kościelnych zawartej w Kodeksie prawa kanonicznego z 1917 roku. Bardziej szczegółowo zostanie zaprezentowana struktura sądu diecezjalnego pierwszej instancji, gdyż cały artykuł otwiera monografię poświęconą Sądowi Diecezjalnemu w Tarnowie w latach 1945-1983.

\section{Struktura sądu zwyczajnego pierwszej instancji}

W każdej diecezji musi być ustanowiony na stałe organ władzy kościelnej - sąd, którego zadaniem jest rozpoznawanie i rozstrzyganie w pierwszej instancji wszystkich spraw cywilnych i karnych przez prawo wyraźnie niewyjętych ${ }^{3}$. W skład sądu wchodzą: sędziowie kościelni, notariusze, promotor sprawiedliwości i obrońca węzła małżeńskiego, woźny i komornik.

\section{I.I. Sędziowie kościelni}

Sędzia jest osobą piastującą publiczny urząd, z którym jest związana kościelna jurysdykcja do rozpatrywania i rozstrzygania sporów z przepisami prawa. Ponadto jest on obdarzony kościelną władzą jurysdykcyjną i wyrokuje na jej mocy, nigdy zaś opierając się na własnym autorytecie, a przedstawiony sobie spór ma rozpoznać i rozstrzygać, odnosząc się do przepisów prawa kanonicznego, a nie do własnych upodobań. Jest też wyznaczony do pełnienia tego urzędu przez właściwą władzę kościelną, a nie wybierany przez strony, czym różni się od sędziego polubownego ${ }^{4}$.

W ustawodawstwie po II wojnie światowej obowiązywały nadal przepisy Kodeksu prawa kanonicznego z 1917 roku. Zatem sędzią mógł być kapłan obdarzony jurysdykcją kościelną z zakresu zewnętrznego dla rozpoznawania spraw cywilnych i karnych. Nie mogli tego urzędu sprawować pozbawieni używania rozumu, nieochrzczeni, laicy oraz duchowni ekskardynowani, suspendowani i obłożeni interdyktem osobistym,

3 Por. Codex Iuris Canonici, Pii X P.M. iussu digestus, Benedicti P. xv auctoritate promulgatus, „Acta Apostolicae Sedis” [dalej: AAs] 9 (1917) pars II, s. 1-593 [dalej: KPK 1917], kan. $1572 \$ 1$.

4 Por. E. Regatillo, Institutiones iuris canonici, Vol. 2, De rebus, de processibus, de delictis et poenisis, Santander 1951, s. 256. 
po wyroku skazującym ${ }^{5}$. Nie mogli być sędziami także apostaci, heretycy i schizmatycy po wyroku ${ }^{6}$, podlegli infamii prawnej ${ }^{7}$, deponowani, pozbawieni na zawsze prawa do noszenia sukni duchownej i degradowani ${ }^{8}$.

Ordynariusz. Sędzią pierwszej instancji dla wszystkich spraw niewyjętych jest w diecezji miejscowy ordynariusz. Może on władzę swą wykonywać osobiście bądź przez innychํ. Biskup nie może sam sądzićwłasnych spraw majątkowych. W razie sporu o prawa majątkowe na rzeczach cudzych, jak służebności lub wierzytelności, albo o dobra doczesne, rzeczy zmysłowe, ruchome lub nieruchome biskupa, prawa lub dobra mensy biskupiej bądź kurii biskupiej ma sprawę rozstrzygnąć miejscowy sąd diecezjalny, składający się z oficjała i dwóch dawniejszych (nominacją) sędziów synodalnych, jeśli biskup na to się zgadza, albo też sąd bezpośrednio wyższy ${ }^{10}$.

Władzę sądowniczą mają również: wikariusz kapitulny, opat i prałat udzielny, wikariusz i prefekt apostolski oraz administrator apostolski ustanowiony na stałe. Wikariusz generalny bez szczególnego zlecenia nie ma władzy sądowniczej ${ }^{11}$.

Oficjał. Każdy biskup musi ustanowić oficjała, któremu z urzędu przysługuje władza sądownicza z zakresu zewnętrznego, zwyczajna, zastępcza. Oficjał nie może być równocześnie wikariuszem generalnym, chyba że diecezja jest stosunkowo mała lub mało jest spraw do sądzenia. Oficjał stanowi z ordynariuszem miejscowym jeden trybunał, stąd też jego wyrok nie wymaga potwierdzenia ze strony ordynariusza miejscowego i nie dopuszcza apelacji do tegoż ordynariusza. Oficjał ma już jurysdykcję dla wszystkich spraw sądowych, z wyjątkiem tych spraw, które biskup diecezjalny sam sobie zastrzegt ${ }^{12}$.

Zgodnie z kan. $1573 \$ 1-3$ oficjałowi można dodać pomocników i zastępców z tytułem wiceoficjałów. Wiceoficjałowie mają władzę zwyczajną. Oficjał i wiceoficjałowie mogą się wzajemnie zastępować w czynnościach

\footnotetext{
5 Por. KPK 1917, kan. 2265, 2266, 2283, 2275 n. 3.

${ }^{6}$ Por. KPK 1917, kan. $2314 \$ 1$.

7 Por. KPK 1917, kan. $2294 \$ 1$.

${ }^{8}$ Por. KPK 1917, kan. 2303, 2304, 2305.

9 Por. KPK 1917, kan. $1572 \$ 1$.

10 Por. F. Bączkowicz, Prawo kanoniczne, dz. cyt., s. 23.

11 Por. KPK 1917, kan. 1573.

${ }^{12}$ Por. F. Bączkowicz, Prawo kanoniczne, dz. cyt., s. 24.
} 
sądowych, nawet $\mathrm{w}$ tej samej sprawie. W sprawach dotyczących administracji sądowej wiceoficjałowie podlegają oficjałowi. W orzekaniu są jednak od niego niezależni i posiadają tę samą władzę.

Kandydaci na urząd oficjała i wiceoficjała (do godziwości mianowania) muszą spełniać następujące kryteria:

- muszą być kapłanami (niekoniecznie diecezjalnymi) dobrego imienia;

- muszą posiadać doktorat prawa kanonicznego albo przynajmniej mieć w nim biegłość;

- muszą liczyć co najmniej 30 lat.

Oficjała i wiceoficjała biskup może dowolnie usuwać. W przypadku opróżnienia stolicy biskupiej nie tracą oni władzy, a wikariusz kapitulny nie może ich usunąć. $Z$ nastaniem nowego biskupa potrzebują jego potwierdzenia (przynajmniej milczącego).

Sędziowie synodalni i prosynodalni. Zgodnie z obowiązującym prawem w każdej diecezji należało ustanowić od 4 do 12 sędziów synodalnych z władzą delegowaną. Pomagali oni biskupowi w sprawowaniu sądownictwa jako członkowie sądu kolegialnego, asesorowie, instruktorzy (audytorzy) lub sędziowie śledczy w sprawach karnych. Wobec sędziów synodalnych stawiano wymóg bycia kapłanem biegłym w prawie kanonicznym. Sposób ich wyboru, a także ich zastępstwa, ustąpienia i usunięcia $z$ urzędu był taki sam jak w przypadku egzaminatorów synodalnych. Sędziów synodalnych proponował biskup na synodzie diecezjalnym, stąd nazwa tego urzędu. Poza synodem - na miejsce zmarłych lub ustępujących sędziów albo jeśli synod nie odbywał się od dziesięcioleci wyznaczał ich biskup po wysłuchaniu zdania kapituły katedralnej, stąd określenie „prosynodalni”. Zarówno sędziowie synodalni, jak i prosynodalni mieli takie same prawa ${ }^{13}$. Sędziowie synodalni oraz prosynodalni mieli władzę delegowaną przez ordynariusza miejscowego ${ }^{14}$, a otrzymywali ją z chwilą mianowania ich na synodzie lub poza nim.

Sądownictwo kościelne w omawianym w tym artykule okresie było wykonywane przez sędziów orzekających jednoosobowo lub kolegialnie. Sędzia zasiadający jednoosobowo mógł sobie dobrać 2 asesorów jako doradców, musiał ich jednak wybrać spośród sędziów synodalnych ${ }^{15}$.

\footnotetext{
13 Por. KPK 1917, kan. 1574.

${ }^{14}$ Por. KPK 1917, kan. $1574 \$ 1$.

15 Por. KPK 1917, kan. 1575.
} 
Sędzią wyrokującym jednoosobowo był ordynariusz miejscowy, oficjał albo wiceoficjał; mógł on rozstrzygać wszystkie sprawy sporne i karne, które nie były zastrzeżone sądowi kolegialnemu przepisem kan. $1576 \$ 1$.

$\mathrm{W}$ ważniejszych sprawach konieczne były sądy kolegialne z oznaczoną liczbą sędziów z głosem decydującym. Tak oto:

- sąd w składzie 3 sędziów rozpoznawał spory cywilne o ważność wyższych święceń oraz o ważność małżeństwa, jak też spory o prawa i majątek kościoła katedralnego. Rozpatrywał też sprawy karne, w których chodziło o odjęcie beneficjum nieusuwalnego lub o wymiar ekskomuniki;

- sąd w składzie 5 sędziów rozpoznawał sprawy karne, za które prawo przewidywało depozycję, pozbawienie na zawsze sukni duchownej lub degradację $e^{16}$;

- ordynariusz miejsca mógł też inne sprawy, zwłaszcza trudniejsze, przekazać sądom złożonym z 3 lub 5 sędzió $w^{17}$.

Instruktor i relator. Audytorem (instruktorem) był sędzia, który w granicach otrzymanego zlecenia, od zawiązania sporu aż do zamknięcia sprawy, wykonywał różne czynności procesowe, jak przesłuchanie świadków lub zebranie dowodów. Audytor miał za zadanie tak przygotować proces, by można go było zakończyć wyrokiem. Od wydania wyroku stanowczego instruktor był wykluczony ${ }^{18}$, o ile nie należał do kolegium sądzącego.

Ordynariusz miejscowy mógł ustanowić jednego bądź kilku instruktorów do wszystkich lub poszczególnych spraw. Sędzia natomiast mógł ustanowić instruktora do sprawy, którą rozpoznawał, o ile ordynariusz nie zarządził inaczej ${ }^{19}$. Instruktorzy zasadniczo byli wybierani spośród sędziów synodalnych, jednak ordynariusz miejsca mógł ich zamianować spoza sędziów synodalnych spomiędzy duchowieństwa swojej lub obcej diecezji albo spośród duchowieństwa zakonnego ${ }^{20}$.

Relatorem (ponensem lub referentem) był jeden z sędziów sądu kolegialnego. Badał on szczegółowo akta sprawy, by je przedstawić in iure

${ }^{16}$ Por. KPK 1917, kan. $1576 \$ 1$.

${ }^{17}$ Por. KPK 1917, kan. $1576 \$ 2$.

18 Por. KPK 1917, kan. 1582.

19 Por. KPK 1917, kan. 1580.

${ }^{20}$ Por. A. Kłódka, Walor sędziów synodalnych, prosynodalnych i pomocniczych w Kodeksie Prawa Kanonicznego 1917 roku, w: Prawo rodzinne, red. A. Dzięga, M. Greszata, P. Telusiewicz, Lublin 2007, s. 304-305 (Kościelne Prawo Procesowe. Materiały i Studia, 4). 
et in facto innym członkom sądu kolegialnego. Relator brał udział w głosowaniu, ustalał brzmienie wyroku i pisał jego tekst. Ponensa wyznaczał przewodniczący składu sędziowskiego, który mógł go usunąć dla słusznej przyczyny i wyznaczyć innego na jego miejsce ${ }^{21}$. Referentem mógł być również sam przewodniczący składu sędziowskiego. Relator mógł być także instruktorem sprawy ${ }^{22}$.

\section{I.2. Notariusz}

Notariuszem była osoba ciesząca się publicznym zaufaniem, która aktom przez siebie lub wobec siebie sporządzonym i podpisanym nadawała charakter dokumentu publicznego. Notariusz (actuarius) należał do personelu sądowego, jednak bez władzy sądowniczej. Zgodnie z kan. 1585 $\$ 1$ musiał brać udział w każdym procesie. Akta procesu były nieważne, jeśli notariusz nie pisał albo przynajmniej nie opatrzył ich swoim podpisem. Musiał on być obecny przy przesłuchaniach, widzieć, co się dzieje, i słyszeć, co się mówi, oraz musiał spisać protokół o czynności dokonanej i go podpisać. $Z$ kolei według kan. $1585 \$ 2$ notariusza ustanawiał ordynariusz miejsca dla poszczególnej sprawy albo przed rozpoczęciem procesu wybierał go sędzia spośród notariuszy kurii biskupiej, prawidłowo mianowanych przez ordynariusza miejscowego dla ogółu spraw. Notariusz mógł być laikiem, jednak w sprawach karnych duchowieństwa musiał być kapłanem ${ }^{23}$.

\section{I.3. Promotor sprawiedliwości i obrońca węzła}

Kodeks prawa kanonicznego z 1917 roku nakazywał obowiązek ustanowienia w każdej diecezji promotora sprawiedliwości oraz obrońcy węzła. Promotor sprawiedliwości z urzędu strzegł interesów publicznych Kościoła w sprawach cywilnych, w których zdaniem ordynariusza chodziło o dobro publiczne. W sprawach zaś karnych występował jako oskarżyciel publiczny.

\footnotetext{
${ }^{21}$ Por. KPK 1917, kan. 1584.

${ }_{22}$ Por. F. Bączkowicz, Prawo kanoniczne, dz. cyt., s. 30.

${ }^{23}$ Por. KPK 1917, kan. $373 \$ 3$.
} 
Z kolei obrońca węzła wyższych święceń i węzła małżeńskiego bronił ważności święceń lub małżeństwa, ilekroć toczył się o to spór. W sprawach, w których obecność promotora lub obrońcy była konieczna, akta były nieważne, jeśli odpowiednia osoba nie została wezwana, chyba że niewezwana, była jednak obecna. Jeżeli została wezwana, ale nie stawiła się, akta były ważne, lecz później musiały jej być przedłożone celem zbadania ${ }^{24}$.

\section{I.4. Woźni i komornicy}

Woźni i komornicy byli osobami pomocniczymi w sądzie. Woźny (cursor) doręczał akta sądowe, natomiast komornik (apparitor) wykonywał z polecenia sędziego wyroki i dekrety. Ta sama osoba mogła sprawować obydwa urzędy ${ }^{25}$.

\section{Sąd drugiej instancji}

Jak twierdzi Tadeusz Pieronek:

Podwaliny najwyższej władzy sądowniczej w Kościele daje prymat św. Piotra i jego następców. Władzy tej podlegają inni biskupi, sami będący sędziami z ustanowienia Bożego. Wokół dwóch, hierarchicznie w stosunku do siebie ustanowionych trybunałów: papieskiego i biskupiego, w ciągu wieków uformowała się cała sieć innych z ustanowienia kościelnego ${ }^{26}$.

W wykonywaniu władzy sądowniczej Kościół przyjmuje prawo apelacji. W ślad za tym idzie konieczność wypowiadania się na ten sam temat wyższego hierarchicznie sądu. Dlatego w Kościele zrodziła się konieczność istnienia oprócz sądów pierwszej instancji trybunałów apelacyjnych drugiej, trzeciej czy dalszych instancji ${ }^{27}$.

${ }^{24}$ Por. KPK 1917, kan. 1587.

${ }_{25}$ Por. KPK 1917, kan. 1591.

${ }^{26}$ T. Pieronek, Normy ogólne kanonicznego procesu sądowego, cz. 1, Warszawa 1970, s. 80.

${ }^{27}$ Por. Z. Janczewski, Właściwość trybunałów kościelnych $w$ sprawach matżeńskich w okresie od 1917 do 1983 roku, „Prawo Kanoniczne. Kwartalnik prawno-historyczny” 38 (1995) nr 3-4, s. 189. 
Pod względem terytorialnym Kościół dzieli się na diecezje i podobne im okręgi. Kilka diecezji tworzy prowincję kościelną lub metropolię. Stąd też sądownictwo kościelne zostało podzielone na sądy diecezjalne i metropolitalne. Spełniają one zadania sądów pierwszej, drugiej czy następnej instancji ${ }^{28}$.

Od wyroku pierwszej instancji wolno było odwołać się do sądu wyższego, jednak według określonego porządku, mianowicie:

- od wyroku sądu diecezjalnego biskupa sufragana należało wnieść apelację do jego metropolity;

- od wyroku biskupa niemającego metropolity nad sobą - do sąsiedniego metropolity, wybranego raz na zawsze na sędziego drugiej instancji przez biskupa za zgodą Stolicy Apostolskiej, zgodnie z kan. 285;

- od wyroku sądu metropolity orzekającego w pierwszej instancji do biskupa wybranego raz na zawsze na sędziego drugiej instancji przez metropolitę za zgodą Stolicy Apostolskiej ${ }^{29}$.

Co do składu osobowego drugiej instancji i trybu postępowania, obowiązywały przepisy dla pierwszej instancji ${ }^{30}$. Jeżeli sąd pierwszej instancji sądził sprawę kolegialnie, sąd drugiej instancji nie mógł się składać z mniejszej liczby sędziów ${ }^{31}$.

\section{Zwyczajne trybunały Stolicy Apostolskiej}

Trzecią instancję - zgodnie z dyspozycją Kodeksu prawa kanonicznego z 1917 roku - stanowi papież, najwyższy w Kościele sędzia. Rozstrzyga on sprawy osobiście albo przez stałe trybunały lub sędziów delegowanych $^{32}$. Zwyczajnymi trybunałami papieża są Rota Rzymska i Sygnatura Apostolska.

Papież piastujący najwyższą na ziemi godność i władzę nie może podlegać żadnej ludzkiej władzy, ani duchownej, ani świeckiej. Sądowi samego papieża, zgodnie z dyspozycją kan. 1557 \$ 1 z 1917 roku, wyłącznie podlegają:

\footnotetext{
${ }^{28}$ Por. Z. Janczewski, Właściwość trybunałów..., dz. cyt., s. 189.

29 Por. F. Bączkowicz, Prawo kanoniczne, dz. cyt., s. 32.

30 Por. KPK 1917, kan. 1595.

31 Por. KPK 1917, kan. 1596.

32 Por. KPK 1917, kan. 1597.
} 
- ci wszyscy, którzy sprawują najwyższą władzę państwową (cesarze, królowie, prezydenci), ich żony, synowie, córki oraz mający wobec nich prawo bezpośredniego następstwa według konstytucji danego państwa;

- kardynałowie od chwili ogłoszenia;

- legaci Stolicy Apostolskiej, czyli legaci a latere, nuncjusze, internuncjusze i delegaci apostolscy w czasie piastowania urzędu, lecz nie nuncjusze tytularni.

\section{I. Rota Rzymska}

$\mathrm{Na}$ temat nazwy Roty Rzymskiej powstało wiele różnych hipotez. Jedna z nich podaje, iż „rota” pochodzi od specjalnego okrągłego regału czy też półki na książki z sali zebrań audytorów. Regał ten mieścił akta procesu oraz inne dokumenty przydatne $\mathrm{w}$ rozpatrywaniu sprawy. Obracając ten mebel, każdy $\mathrm{z}$ audytorów miał w zasięgu ręki potrzebny mu dokument ${ }^{33}$. Inne hipotezy wyprowadzają nazwę Roty od rotacyjnego sposobu rozpatrywania spraw przez poszczególne turnusy składające się z trzech audytorów albo od okrągłej sali, gdzie odbywały się ich spotkania, lub od okrągłego stołu, przy którym zasiadali ${ }^{34}$.

Kodeks prawa kanonicznego z 1917 roku zachował charakter i zasadnicze uprawnienia Roty. Dla postępowania sądowego Roty miarodajne były odtąd normy zawarte w księdze Iv kodeksu, a prawo partykularne Roty zgodnie z kan. 6 n. 1 zachowało swą moc tylko w rzeczach, które są zgodne z przepisami kodeksu. W roku 1934 zostało wydane nowe prawo rotalne, Normae S. Romanae Rotae Tribunalis ${ }^{35}$, które zniosło przeciwne przepisy Reguł Roty. Według kodeksu z 1917 roku Rota działa jako trybunał zwyczajny i jako trybunał nadzwyczajny. Jako trybunał zwyczajny jest ona papieskim trybunałem apelacyjnym $\mathrm{w}$ kościelnych sprawach spornych i karnych wnoszonych do niej z całego świata katolickiego. Sprawy sporne rozpatruje Rota w stopniu apelacyjnym tylko wtedy, gdy $\mathrm{w}$ poprzednich instancjach zostały rozstrzygnięte wyrokiem sądowym

${ }_{33}$ Por. P. Moneta, La giustizia nella Chiesa, Bologna 1993, s. 53.

${ }^{34}$ Por. R. Kantor, Rota Hiszpańska. Struktura i działalność Trybunału Roty Nuncjatury Apostolskiej w Hiszpanii, Tarnów 2013, s. 54-66.

${ }_{35}$ Por. Sacra Romana Rota, Normae S. Romanae Rotae Tribunalis, AAS 26 (1934), s. 449491. 
albo gdy kongregacje skierują do niej sprawy sporne rozpatrywane na drodze administracyjnej, aby je rozstrzygnęła sądownie ${ }^{36}$. Rota rozpatruje w drugiej instancji sprawy rozstrzygnięte $\mathrm{w}$ pierwszej instancji przez jakiegokolwiek ordynariusza, od którego wyroku wniesiono prawidłowo zgłoszoną apelację do Stolicy Apostolskiej ${ }^{37}$, a w ostatniej instancji rozpatruje sprawy rozstrzygnięte przez nią samą lub inny sąd w drugiej lub dalszej instancji, o ile wyroki nie przeszły jeszcze w stan rzeczy osądzonej ${ }^{38}$. Jako trybunał nadzwyczajny sądzi w pierwszej instancji sprawy zastrzeżone trybunałom Stolicy Apostolskiej oraz sprawy powołane przed nią przez papieża motu proprio lub na prośbę stron $^{39}$.

Ponieważ Rota jest trybunałem zwyczajnym tylko do przyjmowania apelacji, w pierwszej instancji sądzi na podstawie zlecenia papieskiego, czyli delegacji. Możliwe są 2 rodzaje delegacji: a iure i ab homine. Delegacja a iure dotyczy spraw zastrzeżonych trybunałom Stolicy Apostolskiej, które wymienione są w kan. 1577 \&2, mianowicie dotyczy: 1) biskupów rezydencjalnych w sprawach spornych z wyłączeniem spraw z kan. 1572 $\$ 2$, tj. spraw i dóbr doczesnych biskupa albo mensy lub kurii biskupiej; 2) diecezji i innych osób moralnych kościelnych, które nie podlegają żadnemu przełożonemu poza papieżem. Delegacja ab homine dotyczy spraw powołanych przez papieża motu proprio lub na prośbę stron przed

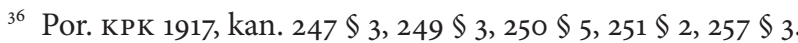

37 Por. KPK 1917, kan. $1599 \$ 1$ n. 1. Przez Stolicę Apostolską rozumie się według kan. 7 również Rotę, dlatego uczestniczy ona w przywileju prymatu papieskiego, na którego mocy można apelować przy pominięciu sędziego apelacyjnego wprost do Stolicy Apostolskiej, czyli do Trybunału Roty. Rota nie może odrzucić skargi apelacyjnej, jeśli jest prawidłowo zgłoszona, a więc jeśli apeluje się od wyroku stanowczego lub przedstanowczego (kan. 1879), od którego prawo pozwala apelować (kan. 188o), oraz jeśli apelacja jest zgłoszona w czasie przydatnym, tj. z zachowaniem terminów zawitych i innych przepisów prawa (kan. 18811886). Jeżeli apelacja w sensie powyższym nie jest prawidłowo zgłoszona, wtedy Rota nie ma kompetencji, chociaż w myśl kan. 1569 każdy wierny może wnieść odwołanie do Stolicy Apostolskiej.

${ }^{38}$ Por. KPK 1917, kan. $1599 \$ 1$ n. 2. Ostatnią instancją jest ta, która nie dopuszcza dalszej, a zachodzi w razie 2 wyroków zgodnych (kan. 1902 n. 1). W sprawach małżeńskich, które nigdy nie przechodzą w stan rzeczy osądzonej, Rota nie przyjmuje dalszej instancji, gdy zapadły 2 zgodne wyroki rotalne. Aby ją otrzymać, trzeba wnieść rekurs do Sygnatury Apostolskiej, która w razie stwierdzenia słuszności rekursu odsyła sprawę ponownie do Roty, chyba że papież zarządzi inaczej (kan. $1604 \$ 3$ ).

${ }^{39}$ Por. KPK 1917, kan. $1599 \$ 2$. 
trybunał Roty. W przypadku tej delegacji, aby poznać zakres władzy delegowanej i sposób postępowania w poszczególnych wypadkach, trzeba według kan. 49 zwrócić uwagę na treść reskryptu oraz na postanowienie kan. $1599 \$ 2$, które stwierdza, że jeśli w reskrypcie nie ma innej klauzuli, to odnosi się on również do instancji apelacyjnej. Spod kompetencji Roty wyjęte są sprawy większe ${ }^{40} \mathrm{i}$ apelacje od zarządzeń administracyjnych ordynariuszy. Definicję spraw większych podaje kan. 220: „Sprawy ważniejszego znaczenia, które czy to z natury swojej, czy też z prawa pozytywnego są zastrzeżone papieżowi, nazywają się sprawami większymi". Z prawa pozytywnego zastrzeżone są papieżowi sprawy, które dotyczą rządców państw, ich żon, dzieci i najbliższych następców, dalej kardynałów i legatów Stolicy Apostolskiej, oraz sprawy karne biskupów, nawet tytularnych (kan. $1557 \$ 1$ ). Z natury swej są zastrzeżone sprawy beatyfikacyjne i kanonizacyjne (Kongregacji Obrzędów, kan. $1999 \$ 1$ ), następnie sprawy podlegające Kongregacji Świętego Oficjum, rozpatrywane na drodze procesu sądowego (Kongregacji Świętego Oficjum, kan. $247 \$ 2-3$ ), wreszcie sprawy obowiązków przywiązanych do wyższych święceń (Kongregacji Sakramentów, kan. 249 \$3).

\subsection{Sygnatura Apostolska}

Według Bączkowicza w XIII wieku osobni urzędnicy przedstawiali papieżowi zaniesione do niego prośby o udzielenie łaski lub rozstrzygnięcie sporu, przygotowaną zaś odpowiedź przedkładali mu do podpisu, i stąd zwali się „Referendarii Signaturae”. Były 2 sygnatury: gratiae, dla udzielania łask i przywilejów, oraz iustitiae, dla wymierzania sprawiedliwości ${ }^{41}$.

Zgodnie z dyspozycją kan. 1602 KPK 1917 Sygnatura Apostolska jest sądem kolegialnym składającym się z kilku kardynałów wyznaczonych przez papieża. Jeden z nich jest jej prefektem. Ponadto w Sygnaturze są inni urzędnicy, jak sekretarz, notariusz, konsultorzy.

$\mathrm{Na}$ mocy władzy zwyczajnej Sygnatura Apostolska rozpatruje:

- sprawy o złamanie sekretu i o szkody wyrządzone przez audytorów Roty Rzymskiej wskutek aktu nieważnego lub niesprawiedliwego;

\footnotetext{
${ }^{40}$ Por. KPK 1917, kan. 1600.

${ }^{41}$ Por. F. Bączkowicz, Prawo kanoniczne, dz. cyt., s. 36.
} 
- zarzuty stronniczości przeciw audytorom Roty Rzymskiej. W tym przypadku Sygnatura rozstrzyga, czy zarzut należy uwzględnić czy nie, po czym odsyła sprawę do Roty;

- skargi o nieważność wyroków Roty;

- wnioski o przywrócenie do stanu poprzedniego przeciwko wyrokom Roty, które już przeszły w stan rzeczy osądzonej;

- rekursy przeciwko wyrokom Roty Rzymskiej w sprawach małżeńskich, których Rota nie chce przyjąć do ponownego rozpatrzenia;

- spory kompetencyjne powstałe między niższymi trybunałami, a wniesione do Sygnatury zgodnie z kan. $1612 \$ 2$ KPK 1917.

Natomiast na mocy władzy delegowanej Sygnatura rozpatruje wniesione do papieża podania o przekazanie jakiejś sprawy do Roty Rzymskiej. Po zasięgnięciu informacji i wysłuchaniu osób zainteresowanych rozstrzyga o tym, czy prośbę uwzględnić czy nie.

Wyroki Sygnatury Apostolskiej zgodnie z postanowieniem kan. 1605 KPK 1917 mają moc prawną, nawet gdyby nie podano w nich prawnych i faktycznych powodów. Apelacje przeciwko wyrokom Sygnatury są wykluczone ${ }^{42}$.

${ }^{42}$ Por. KPK 1017, kan. 188 o n. 1. 